\title{
Analyzing Universities Service Quality to Student Satisfaction; Academic and Non-Academic Analyses
}

\author{
Kardoyo $^{1}$, Lola Kurnia Pitaloka ${ }^{1}$, Rozman $^{1}$ \& Bayu Bagas Hapsoro ${ }^{2}$ \\ ${ }^{1}$ Economics Education, Faculty of Economics, Universitas Negeri Semarang, Indonesia \\ ${ }^{2}$ Universitas Teknologi Mara, Malaysia \\ Correspondence: Lola Kurnia Pitaloka, Economics Education, Faculty of Economics, Universitas Negeri Semarang, \\ Indonesia. E-mail: lolakp@mail.unnes.ac.id
}

Received: October 30, 2019

Accepted: November 26, 2019

Online Published: December 4, 2019

doi:10.5430/ijhe.v9n1p126

URL: https://doi.org/10.5430/ijhe.v9n1p126

\begin{abstract}
Indonesia has many higher learning institutions both public and private sectors such as colleges, polytechnics, institutes and universities and they are competing among them to get students to enroll in their institutions. It has become competitive among them to get students than before. The growing competition among higher learning institutions had forced them to strive to improve their service quality provided to students. The student satisfaction of service quality can be divided into two parts, namely satisfaction in academic and non-academic. The purpose of this research is to determine whether the academic and non-academic service quality affect student satisfaction of Economics Faculty Universitas Negeri Semarang. This research used an exploratory method that explaining the relationship between hypothesis testing, making prediction and getting the implicit meaning of problems that want to be solved. This study was conducted at the Economics Faculty of Universitas Negeri Semarang. The data analysis used SEM PLS. The population in this study were students from the Economics Faculty of Universitas Negeri Semarang who registered in 2015 and graduated in 2018. The total number of population in this study were 3,596 students majoring in Economics Education, Accounting, Management, and Economic Development. This study used a stratified sampling technique where students from all disciplines and levels were determined using the Slovin formula. Questionnaires were distributed to a sample of 360 students and were administered by trained enumerators. Data were collected using self-administered assessment questionnaires of a five Likert scale and analyzed using SEM PLS 6.0 Warp PLS. The results of this research were, first, academic service quality did not influence student satisfaction. Second, the non-academic service quality has a positive and significant influence on student satisfaction. This is because the supported learning infrastructure was found to be a factor that satisfied the students compared to teaching methods that was carried out by faculty members. It was also found that attitude and behavior in academic aspect were not significant in improving the students' satisfaction. Therefore, it is suggested that Faculty of Economics of UNNES should focus on maintaining and improving the service quality of non-academic aspects in order to compete with other higher learning institutions.
\end{abstract}

Keywords: service quality, student satisfaction, universities, academic, non-academic

\section{Introduction}

There are many higher learning institutions in Indonesia both public and private sectors such as colleges, polytechnics, institutes and universities and they are competing among them to get students to enroll in their institutions. They need to reform themselves, including the services provided to students due to intense competition among higher learning institutions. Electoral colleges are not spared from this phenomenon where the elements of service offered by the institutions and student satisfaction were determined by the services provided by them. Therefore, they must provide an excellent service to their students in order to compete in the business of education.

There are 122 public higher learning institutions in Indonesia and 3,154 private colleges. Students in Indonesia prefer to study in private colleges than public institutions because of various factors and private colleges are competing among them in providing good education services to students. This is a good trend as service quality of an institution is the main focus in attracting more students to enroll into the institutions.

Semarang, a province in Central Java has a lot of higher learning institutions in Indonesia. There are 256 private institutions and 9 public universities. Even though many people prefer to enroll into public universities but most of them choose private colleges because of their good service quality lately especially academic services. Universitas 
Negeri Semarang a public university in Central Java has eight faculties and Economics Faculty is one of the faculty in UNNES that started in 2006. Before 2006, the Economics Faculty was just an economics department and incorporated in the Social Sciences Faculty. Economics Faculty of UNNES always improve its services to their students from time to time by providing regular questionnaires to determine student satisfaction with the services that have been given over the years. The effective way to improve its services includes quality of care such as physical evidence (tangible), empathy (empathy), durability (responsiveness), reliability (reliability), and certainty (assurance) as an effort to fulfill the needs and desires of the community. In line with a research conducted by Teeroovengadum et al. in 2016, it was found that the college students in Mauritius were satisfied with the quality of service provided by their respective colleges. Some of the factor analysis of service quality of higher learning institutions obtained in the study were (1) an administrative quality; (2) the quality of the physical environment; (3) The core of education quality; (4) the quality of support facilities; and (5) the quality of the transformation.

In another research by Pham et al. (2016) in Vietnam found that the perceptions of service quality were different from the previous studies, whereby the concept of service quality in universities was based on the output of the graduates. The main focus of service quality at several universities in Vietnam is to prepare graduates who could fulfill the demand of the industry and adapt to the work environment because if a university could produce good graduates, then it will give a good impact to the university's image and popular in the community. In short, there are two different perceptions of service quality in higher learning institutions between the two countries. In Mauritius, the service quality was based on the students' satisfaction of the services provided by the universities while in Vietnam it was based on the outcome of the graduates. However, the main focus of service quality of higher learning institutions in most research lead to the increasing popularity of a university where satisfaction on its service quality could encourage the community to promote it to others. The purpose of this research was to determine the extent to which service quality of academic and non-academic aspects has an impact towards the student satisfaction of Economics Faculty. The findings of this study could assist the university to improve its service quality of academic and non-academic aspects in the future in the effort to increase students' enrolment and enhance the body of knowledge of this theory.

Quality is a dynamic condition associated with products, services, people, processes and environments that meet exceeding expectations. Service is an invisible activity that occurs due to the interaction between costumers and employees provided by a company. A good service quality will encourage customers to commit with products or services of a company that will have an impact on the increase in market share. According to Smith (2007), in general customer perception of service quality can be measured and evaluated through service quality dimensions, namely, (1) Tangibles, which include physical facilities, employee performance, the equipment used and the physical presentation; (2) Reliability, the ability to deliver the promised services are reliable and precise; (3) Responsiveness, the willingness or readiness of employees to provide service and help costumers; (4) Assurance, the knowledge, courtesy, and ability of employees to gain the trust of customers and (5) Empathy, care and attention of companies individually to the costumer.

This research adopted the indicators from Ali et al. (2016) who formulated some indication of factors that can affect the service quality of student satisfaction, namely (1) the academic aspect; (2) non-academic aspects; (3) the availability of the program; (4) reputation; and (5) access. But this research used only two factors: academic and non-academic aspects because these two variables were widely used by other researchers. The indicators of academic aspects include administrative processes, curriculum, attitudes and behavior, and competence, while the indicators of non-academic aspects are supporting facilities, supporting infrastructure and public infrastructure (Teeroovengadum, 2016).

Satisfaction would arise if the needs and desires of a costumer or customer matched with the quality of goods or services. Satisfaction of a customer towards a product is determined by the acceptance behavior that appears after using the products or services. In higher learning institutions the customers are students because they pay educational fees for each semester of their studies and in return they expect to get better service quality provided by their universities such as services, facilities, faculties and leadership qualities and each student has a different perception from one another. According to Petruzzellis (2006), there are several indicators of student satisfaction, namely, (1) Reliability, a comparison between the expectations of the costumers' perception of the ability to provide services that have been promised to quickly and precisely. Covering the speed of service delivery, qualified people who provide service and promptness of service delivery; (2) Product-related Information, including facilities and infrastructures, accuracy suggestions and explanations, and (3) Commercial Colleges, includes hospitality services and facilities for obtaining information. 
This study wanted to find out more about which aspects between the academic aspects and non-academic aspects that more influence student satisfaction with the services provided by the campus. By knowing which aspects are stronger, this research can make evaluation materials for all higher education, especially for Universitas Negeri Semarang, to improve the quality of services that are felt to be inadequate and needed by students.

\section{Method}

This study used the exploratory methods which created a picture of the situation or phenomenon. This method described a relationship, hypotheses testing, make predictions, and get the implicit meaning of a problem to be solved. The study was conducted at the Economics Faculty, Universitas Negeri Semarang and used primary data through questionnaires that were distributed to its students. Data were collected using self-administered assessment questionnaires of a five Likert scale and analyzed using SEM PLS 6.0 WarpPLS. The purpose of using these techniques was to develop a theory for the prediction of interest concerning the factors of service quality. The population in this study were students from the Economics Faculty of Universitas Negeri Semarang who registered in 2015 and graduated in 2018. The total number of population in this study were 3,596 students majoring in Economics Education, Accounting, Management, and Economic Development. This study used a stratified sampling technique where students from all disciplines and levels were determined using the Slovin formula. Questionnaires were distributed to a sample of 360 students and were administered by trained enumerators.

\section{Results}

Common methods bias or bias test were used to verify if the scale used to measure data meet the requirement for the statistical analysis such as errors and so forth. In this study, a common test method explanations were derived from the full value of collinearity VIFs, a full collinearity test results which include vertical and lateral multicollinearity and the criteria for full collinearity VIFs should be <3.3. Results in the table 1 shows that the full value of all the variables collinearity VIFs is $<3.3$, which means that the model had met the requirement for the statistical analysis and could be employed and further analyzed in this study.

Table 1. Full Collinearity VIFs Value

\begin{tabular}{cc}
\hline Variable & $\begin{array}{c}\text { Full Collinearity } \\
\text { VIFs }\end{array}$ \\
\hline Service Quality & 1,031 \\
Academic Aspect & 1,012 \\
Non-Academic Aspect & 1,031 \\
Student Satisfaction & 1,032 \\
\hline
\end{tabular}

Source: data processed 2019

This model testing criteria was set to fit with the model and quality indices and the results are shown in Table 2 .

Table 2. Model Fit and Quality Indices

\begin{tabular}{|c|c|c|c|c|}
\hline No & Model Fit and Quality Indices & Fi criterion & Analysis Result & Information \\
\hline 1 & APC & $\mathrm{P}<0.05$ & $\begin{array}{c}0.145 \\
P<0.001\end{array}$ & Well \\
\hline 2 & ARS & $\mathrm{P}<0.05$ & $\begin{aligned} & 0.034 \\
P & <0.001\end{aligned}$ & Well \\
\hline 3 & AARS & $\mathrm{P}<0.05$ & $\begin{aligned} & 0.030 \\
P & <0.001\end{aligned}$ & Well \\
\hline 4 & AVIF & Acceptable if $<=5$, ideally $<=3.3$ & 1.046 & Ideal \\
\hline 5 & AFVIF & Acceptable if $<=5$, ideally $<=3.3$ & 1.026 & Ideal \\
\hline 6 & GoF & $\begin{array}{c}\text { Small }>=0.1, \text { medium }>=0.25, \\
\text { large }>=0.36\end{array}$ & 0.086 & $\begin{array}{l}\text { Ideal } \\
\text { (Small) }\end{array}$ \\
\hline 7 & SPR & Acceptable if $>=0.7$, ideally $=1$ & 1.000 & Ideal \\
\hline 8 & RSCR & Acceptable if $>=0.9$, ideally $=1$ & 1.000 & Ideal \\
\hline 9 & SSR & Acceptable if $>=0.7$ & 1.000 & Ideal \\
\hline 10 & NLBCDR & Acceptable if $>=0.7$ & 0.875 & Ideal \\
\hline
\end{tabular}

Source: data processed 2019 
Table 2 shows the results of the model fit and quality indices that were qualified for the processing and analysis of data because the data used in the model is good or ideal in testing the proposed hypotheses. The purpose of testing this model is to look at the direction and magnitude of the coefficient relationship between variables. Diagram 1 below shows the result of the research model that had been tested:

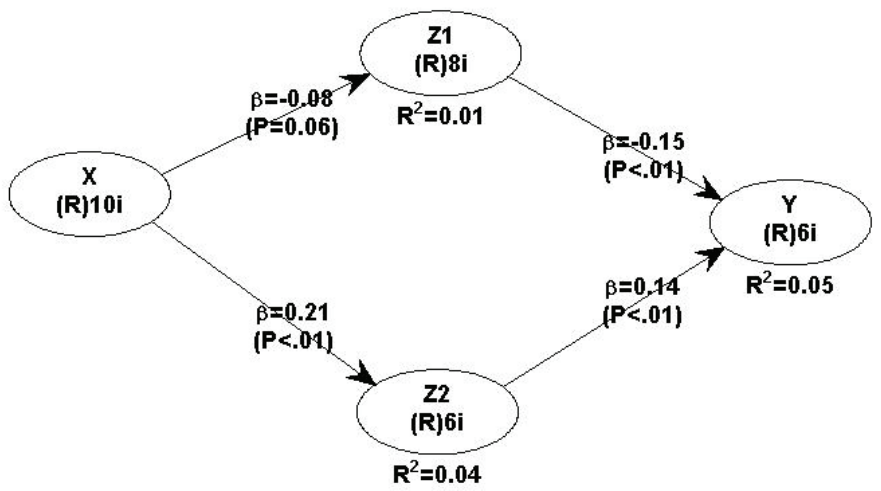

Figure 1. Research Model

Model testing above illustrates the flow from the analysis of the model in this research. The finding shows that there is a negative coefficient in the groove, which means service quality of academic aspects did not affect students' satisfaction. As already described, the variables that have an influence on dependent variable are eligible p-value $<0.01$, respectively. Data testing of models is presented in tabular form below:

Table 3. Result of Research Model

\begin{tabular}{|c|c|c|c|c|}
\hline \multicolumn{3}{|l|}{ Lane } & Coefficient & P-Value \\
\hline \multicolumn{3}{|c|}{ Service Quality to Academic Aspects } & -0.08 & $\mathrm{P}=0,06$ \\
\hline $\begin{array}{l}\text { Service Quality to } \\
\text { Aspects }\end{array}$ & Non- & cademic & 0,21 & $\mathrm{P}<0,01$ \\
\hline $\begin{array}{l}\text { Academic Aspects } \\
\text { Satisfaction }\end{array}$ & to & Student & $-0,15$ & $\mathrm{P}<0,01$ \\
\hline $\begin{array}{l}\text { Non-Academic Aspects } \\
\text { Satisfaction }\end{array}$ & to & Student & 0,14 & $\mathrm{P}<0,01$ \\
\hline
\end{tabular}

Source: data processed 2019

Table 3 shows that academic aspects did not contribute to service quality when the result indicate a negative coefficient and the $\mathrm{p}$ values is $>0.01$. Furthermore, the academic aspects as a moderating variable did not have an effect on the relationship between service quality and student satisfaction. Hence, the hypothesis of the influencing factor of the academic aspects of service quality to satisfaction of students of the Economics Faculty, Universitas Negeri Semarang is rejected. Academic aspects in this research refer to the administrative process practiced by staff on students, the curriculum provided by the faculty for lecturers, attitudes, and behavior shown by educators and academic staff to students as well as the competency of educators and other education personnel. However, aspects of attitude and behavior in this study should be omitted because it contributed to low-value AVE. As described in Cheruiyot and Maru's (2013) attitudes and behavior of a lecturer did not affect the satisfaction of students during lectures because students generally did not pay attention to the attitude and behavior of a teacher but the attention was on what is being described by the lecturers. Cheruiyot and Maru's further reiterated that even though some of the teachers did not show good attitudes and behavior during lecturers but it won't be a major problem to students because the lecturer could continue giving lecturers in a comfortable classroom atmosphere and it won't create tension in the classroom. Nevertheless, findings from a research conducted by Moyo and Ngwenya (2018) shows a contradictory result when attitudes and behavior of faculty personnel greatly affect student satisfaction. The research findings revealed that students were concerned with the attitude and behavior of their lecturers during lectures. The research findings in this study shows that the attitudes and behavior in academic aspect contributed to low-value AVE because students were not concerned with the attitude and behavior of the lecturers and other education 
personnel. Students were more satisfied with enjoyable atmosphere in the classroom rather than with the attitude and behavior of their lecturers.

Table 3 also shows that non-academic service quality has an effect and significant to student satisfaction but the significance value too low. One of the indicators of the non-academic aspects that create low value of AVE is supporting infrastructure such as a field, laboratory, and other special space. Economics Faculty UNNES has many laboratories that were used to develop courses and discussions by lecturers in a certain particular lab and sometimes used by them too to conduct lectures. Students were not happy with this phenomenon because they were unable to make full use the laboratories as usual.

Results from this study differ from research findings by Teeroovengadum (2016) even though both have the same indicators. Teeroovengadum didn't remove the supporting infrastructure indicators it had an influence on non-academic aspects where the value of the non-academic aspects AVE was higher. His research findings is also supported by another research done by Wong (2013) revealing that supporting infrastructure was one of influential indicator for the non-academic aspects towards satisfaction of students. Laboratory became an important infrastructure needed by students because apart from attending lectures they also conduct research for research based subject and gain information from the laboratory as well as the library. Therefore, service quality of non-academic aspects has a good impact on student satisfaction.

This study is contrary to Sultan and Wong (2010) which stated that supporting infrastructure such as laboratories had an obvious effect on student satisfaction. Laboratory was regarded as one of the rooms other than classroom for students to develop their science knowledge with the facilities provided by the university. Research findings by Bellamkonda (2016) was also in line with Sultan and Wong where a complete laboratory space owned by the university could increase student satisfaction in developing their science knowledge after library. Students should be allowed to use both places at any time. Nevertheless, the awareness of the importance of laboratories and dedicated space that has been provided for learning is low for students in the Economics Faculty of UNNES despite encouragement and easy access to all laboratories to support the process of their learning process. It was found out that students prefer academic discussion to be carried out outdoor rather than indoor.

Recent research from Amegbe, et. al (2019) proved that product-related information relating to the accuracy of the advice and explanations in the service quality is an important indicator that could increase student satisfaction. It is inversely proportional to the results of this study in which indicators of product-related information was not able to increase student satisfaction and eventually being removed as indicators of student satisfaction. It was found students from the Faculty of Economics UNNES were reluctant to listen to the explanation and suggestion about the service quality provided to them. This is supported by research conducted by Ahmed (2016) in which some of the students in Malaysia also refused to listen to the explanations and advice about service quality that were provided by the university but they only want a better service.

\section{Discussion}

Results from this study differ from research findings by Teeroovengadum (2016) even though both have the same indicators. Teeroovengadum didn't remove the supporting infrastructure indicators it had an influence on non-academic aspects where the value of the non-academic aspects AVE was higher. His research findings is also supported by another research done by Wong (2013) revealing that supporting infrastructure was one of influential indicator for the non-academic aspects towards satisfaction of students. Laboratory became an important infrastructure needed by students because apart from attending lectures they also conduct research for research based subject and gain information from the laboratory as well as the library. Therefore, service quality of non-academic aspects has a good impact on student satisfaction.

This study is contrary to Sultan and Wong (2010) which stated that supporting infrastructure such as laboratories had an obvious effect on student satisfaction. Laboratory was regarded as one of the rooms other than classroom for students to develop their science knowledge with the facilities provided by the university. Research findings by Bellamkonda (2016) was also in line with Sultan and Wong where a complete laboratory space owned by the university could increase student satisfaction in developing their science knowledge after library. Students should be allowed to use both places at any time. Nevertheless, the awareness of the importance of laboratories and dedicated space that has been provided for learning is low for students in the Economics Faculty of UNNES despite encouragement and easy access to all laboratories to support the process of their learning process. It was found out that students prefer academic discussion to be carried out outdoor rather than indoor.

Recent research from Amegbe, et. al (2019) proved that product-related information relating to the accuracy of the 
advice and explanations in the service quality is an important indicator that could increase student satisfaction. It is inversely proportional to the results of this study in which indicators of product-related information was not able to increase student satisfaction and eventually being removed as indicators of student satisfaction. It was found students from the Faculty of Economics UNNES were reluctant to listen to the explanation and suggestion about the service quality provided to them. This is supported by research conducted by Ahmed (2016) in which some of the students in Malaysia also refused to listen to the explanations and advice about service quality that were provided by the university but they only want a better service.

As a conclusion, service quality viewed from the academic aspect is not able to influence students satisfaction compared to when viewed from non-academic aspects. Which means everything related to non-academic aspects at the Faculty of Economics of Universitas Negeri Semarang must be improved in order to increase students satisfaction. The quality of service seen from the academic aspect does not really matter to students, such as the curriculum or the behavior of lecturers or faculty staff. The satisfaction of students at the Faculty of Economics of Universitas Negeri Semarang is stronger when they are satisfied with the non-academic aspects that support their learning both in class and in out of class (group discussion outside the classroom). This research have the limitation on the measurement for the academic aspects that only focus on administration process, curriculum, behavior of lecturers and faculty staff and compentence. So for the future research, hope can add the indicators for academic aspects. May the added indicator can make service quality viewed from academic aspects can influence the students satisfaction of higher education.

\section{References}

Abouchedid, Kamal. \& Nasser, Ramzi. (2002). Assuring Quality Service in Higher Education: Registration and Advising Attitudes in a Private University in Lebanon, Quality Assurance in Education, 10(4), 198-206, https://doi.org/10.1108/09684880210446866

Ahmed, Yit Sean Chong Pervaiz. (2014). A Phenomenology of University Service Quality Experience, International Journal of Educational Management, 28(1), 36-52, https://doi.org/10.1108/IJEM-01-2013-0004

Ali, Faizan., Zhou, Yuan., Hussain, Kashif., Nair, Pradeep Kumar. \& Ragavan, Neethiahnanthan Ari. (2016). Does Higher Education Service Quality Effect Student Satisfaction, Image \& Loyalty? A Research of International Students in Malaysian Public Universities, Quality Assurance in Education, 24(1), 70-94.

Amegbe, Hayford., Hanu, Charles. \& Mensah, Farouq. (2019). Achieving Service Quality and Students Loyalty Through Intimacy and Trust of Employees of Universities. A Test Case of Kenyan Universities, International Journal of Educational Management, https://doi.org/10.1108/IJEM-09--2017-0251.

Bellamkonda, Subrahmanyam \& Annamdevula Raja Shekhar. (2016). Effect of Student Perceived Service Quality on Student Satisfaction, Loyalty and Motivation in Indian Universities: Development of HiEduQual, Journal of Modelling in Management, 11(2), 1-41, https://doi.org/10.1108/JM2-01-2014-0010

Cheruiyot, Thomas K. \& Maru, Loice C. (2013). Service Quality and Relative Performance of Public Universities in East Africa, The TQM Journal, 25(5), 533-546, https://doi.org/10.1108/TQM-11-2012-0103

Douglas, Jacqueline., Douglas, Alex. \& Barnes, Barry. (2006). Measuring Student Satisfaction at a UK University, Quality Assurance in Education, 14(3), 251-267, https://doi.org/10.1108/09684880610678568

Galeeva, Railya B. (2016). SERVQUAL Application and Adaptation for Educational Service Quality Assessments in Russian Higher Education, Quality Assurance in Education, 24(3), 329-348.

Kemenristekdikti. (2017). Statistik Pendidikan Tinggi Tahun 2017. Jakarta. Pusdatin Iptek Dikti, Setjen, Kemenristekdikti 2017.

Khoo, Susie., Ha, Huong. \& McGregor, Sue L.T. (2017). Service Quality and Student/Customer Satisfaction in the Private Tertiary Education Sector in Singapore. International Journal of Educational Managemenet, 31(4), 430-444, https://doi.org/10.1108/IJEM-09-2015-0121

Kitcharoen, Krisana. (2004). The Importance Performance Analysis of Service Quality in Administrative Departments of Private Universities in Thailand, ABAC Journal, 24(3), 20-46.

Manaf, Noor Hazilah Abd., Ahmad, Khaliq. \& Ahmed, Selim. (2013). Critical Factors of Service Quality in a Graduate School of Malaysia. International Journal of Quality and Service Sciences, 54(3), 415-431, https://doi.org/10.1108/IJQSS-07-2012-0006

Moyo, Arnold. \& Ngwenya, Sothini. (2018). Service Quality Determinants at Zimbabwean State Universities. 
Quality Assurance in Education, https://doi.org/10.1108/QAE-07-2016-0036.

Petruzzellis, Luca., D’Uggento, Angela Maria. \& Romanazzi, Salvatore. (2006). Student Satisfaction and Quality of Service in Italian Universities. Managing Service Quality, 16(4), 349-364, https://doi.org/10.1108/09604520610675694

Pham, Huong Thi. \& Starkey, Louise. (2016). Perceptions of higher Education Quality at Three Universities in Vietnam. Quality Assurance in Education, 24(3), 369-393, https://doi.org/10.1108/QAE-07-2014-0037

Smith, Gareth., Smith, Alison. \& Clarke, Alison. (2007). Evaluating Service Quality in Universities: a Service Department Perspective. Quality Assurance in Education, 15(3), 334-351.

Sultan, Parves. \& Wong, Ho Yin. (2013). Antecedents and Consequences of Service Quality in a Higher Education Context. Quality Assurance in Education, 21(1), 70-95, https://doi.org/10.1108/09684880710773200

Sultan, Parves. \& Wong, Ho Yin. (2013). Antecedents and Consequences of Service Quality in a Higher Education Context. Quality Assurance in Education, 21(1), 70-95, https://doi.org/10.1108/09684881311293070

Sultan, Parves. \& Wong, Ho. (2010). Performance-based Service Quality Model: An Empirical Research on Japanese Universities. Quality Assurance in Education, 18(2), 126-143, https://doi.org/10.1108/09684881011035349

Tan, Kay C. \& Kek, Sei W. (2004). Service Quality in Higher Education Using an Enhanced SERVQUAL Approach. Quality in Higher Education, 10(1), 16-24, https://doi.org/10.1108/QAE-06-2014-0028

Yeo, Roland K. (2008). Servicing Service Quality in Higher Education: Quest for Excellence. On the Horizon, 16(1), 152-161, https://doi.org/10.1108/10748120810901459 